\title{
Seasonal relationships between cyst germination and vegetative population of Scrippsiella trochoidea (Dinophyceae)
}

\author{
Young-Ok Kim, Myung-Soo Han* \\ Department of Life Science, Hanyang University, Seoul 133-791, Korea
}

\begin{abstract}
The seasonal occurrence of vegetative cells and cysts of the dinoflagellate Scrippsiella trochoidea in the water column was investigated in Yongil Bay (southeastern coast of Korea). To measure germination ratios of cysts, cysts were isolated monthly from natural sediment samples and incubated in the laboratory. Vegetative cell numbers peaked in June to July, when the surface water temperature increased to over $18^{\circ} \mathrm{C}$. Mass encystments were detected in the water column in August 1996 and July 1997, when the vegetative population flourished. Active germination was observed during the period of decreasing water temperature in September and October, when the vegetative population declined. Thus, there was an opposing pattern of seasonality in the potential germination of cysts and the proliferation of vegetative cells, whereby decreases in one paralleled increases in the other. The dormant period of cysts was ca $60 \mathrm{~d}$, far longer than reported previously. Germination ratios increased in October 1996 and September 1997 after a 2 mo dormancy period following the mass encystments. Germination appears to be flexible with respect with length of dormancy and the age composition of cysts, both of which are based on the time and the scale of encystments as well as on conditions in the benthic environment.
\end{abstract}

KEY WORDS: Scrippsiella trochoidea · Cyst germination · Vegetative population · Dormant period

\section{INTRODUCTION}

Dinoflagellate blooms are often linked to encystment and excystment; thus, the timing and location of dinoflagellate blooms may be predicted by studying the abundance and distribution of cysts in the sediment. Many studies on the distribution of dinoflagellate cysts have been carried out in temperate and boreal zones (e.g., Reid 1972, Wall et al. 1977, Harland 1983, Nehring 1994).

Dinoflagellate resting cysts are a product of a sexual life cycle. Cysts germinate into vegetative cells after a dormant period, and are sometimes thought to provide the inoculum for bloom initiation in the water column (Anderson \& Wall 1978, Walker \& Steidinger 1979). Therefore, it is expected that the cyst or seed popula-

*Corresponding author. E-mail: hanms@email.hanyang.ac.kr tion should actively germinate before the bloom of the vegetative population. Active germination preceding the bloom of the toxic dinoflagellate Alexandrium tamarense (Anderson \& Morel 1979, Anderson \& Keafer 1985) supports this scenario.

The vegetative cell of the dinoflagellate Scrippsiella trochoidea is distributed mainly in coastal waters in middle and low latitudes (Wall et al. 1970), and is one of the causative species of red tides in Japan, Korea and China (Adachi 1972, Park et al. 1989, Qin et al. 1997). Its cysts are known from the northeastern Pacific coast of Japan (Ishikawa \& Taniguchi 1994), and occur widely in the Caribbean area, the eastern coast of the USA, the southern central and eastern Mediterranean, West Africa, and the coast of Peru (Wall et al. 1970). Thus, S. trochoidea is recognized as being successfully adapted to a wide variety of environmental conditions. The vegetative cells of $S$. trochoidea proliferate in a broad range of temperatures 
(10 to $30^{\circ} \mathrm{C}$ ) and salinities (5 to $55 \%$ ) (Braarud 1951, Silva 1962), and maintain viability even at $5^{\circ} \mathrm{C}$ (Ishikawa 1995). Furthermore, $S$. trochoidea cysts are very convenient for experimental purposes because their sorting and culturing is comparatively easy, the cysts being relatively abundant in sediments.

However, there is little information about the population dynamics of Scrippsiella trochoidea, despite its quantitative importance as both vegetative cells and cysts, because most studies of dinoflagellates have focused on toxic species such as Alexandrium tamarense. Recently, a serial study on the population dynamics of $S$. trochoidea was accomplished in Onagawa Bay, northeast Japan (Ishikawa \& Taniguchi $1994,1996)$. One notable result was that bloom initiation of $S$. trochoidea is not necessarily a direct consequence of mass cyst germination. Instead, the blooms can be initiated by a very small number of vegetative cells. The cysts generally germinate after the bloom of the vegetative population, but not before. The temporal discrepancy between the peak of vegetative populations and the peak of germination rates has also been demonstrated in other dinoflagellate species (Ishikawa \& Taniguchi 1997).

More accurate understanding of the population dynamics of Scrippsiella trochoidea is needed to determine if there are geographic differences between populations. In particular, the life-cycle dynamics should be analyzed with respect to adaptation to a specific environment. Therefore, this study examined the seasonal relationships between germination and blooms of $S$. trochoidea, the dominant dinoflagellate species along the southeastern coast of Korea, to confirm a temporal discrepancy between germination and bloom. Additional information on the cyst was provided from a combination of field and laboratory observations.

\section{MATERIALS AND METHODS}

Water sampling and processing. Sampling was conducted at $36^{\circ} 02^{\prime} \mathrm{N}, 129^{\circ} 23^{\prime} \mathrm{E}$ in the innermost part of Yongil Bay on the southeastern coast of Korea (Fig. 1). Average water depth at the station is $7 \mathrm{~m}$. From July 1996 to October 1997, water samples were collected monthly at 2 and $6 \mathrm{~m}$ depth with a Van Dorn bottle. The water samples were fixed immediately in 5\% (v:v) Bouin's fixative. Vegetative cells and cysts of Scrippsiella trochoidea in the fixed water samples were counted separately. The abundance of the vegetative population was estimated using the quantitative protargol staining method (Montagnes \& Lynn 1987), which is useful to identify and enumerate small phytoplankton by microscopic observation at higher magnification. Depending on the density of cysts, a 10 to $100 \mathrm{ml}$ aliquot of the fixed samples was concentrated by sieving through $20 \mu \mathrm{m}$ mesh. The cysts were counted in a Sedgwick-Rafter chamber. Water temperature and salinity were recorded with a digital bathythermograph at each sampling. Dissolved oxygen was measured by the Winkler method (Parsons et al. 1984). Nutrients $\left(\mathrm{NO}_{3}{ }^{-}, \mathrm{NO}_{2}{ }^{-}, \mathrm{NH}_{4}{ }^{+}\right.$, and $\left.\mathrm{PO}_{3}{ }^{-}\right)$in filtered water were analyzed on an autoanalyzer (SKALAR 5100).

Sediment sampling and processing. Sediment samples were taken monthly with a hand corer at the same time as the water samples. The top $3 \mathrm{~cm}$ of 3 cores were transferred to a plastic vessel and stored in the dark at $5^{\circ} \mathrm{C}$ until sorting of the cysts. The sorting was carried out mainly by the panning method (Matsuoka et al. 1989); seawater collected at $6 \mathrm{~m}$ depth during each sampling date was passed through a 0.2 or $0.8 \mu \mathrm{m}$ filter and used during cyst isolation and culture. Briefly, the sediment in the vessel was mixed well and $1.0 \mathrm{~g}$ wet wt was transferred to cooled, filtered seawater and sonicated for $30 \mathrm{~s}$. The suspension was serially sieved through 100 and $20 \mu \mathrm{m}$ mesh, and the residue on the latter was washed into a watch glass. By panning on the watch glass, cysts and light particles were separated from heavier sand grains and were sieved again onto the $20 \mu \mathrm{m}$ sieve and concentrated to a final sample volume of $10 \mathrm{ml}$.

Cyst germination experiments. Of the $10 \mathrm{ml}, 1 \mathrm{ml}$ was placed in a Sedwick-Rafter chamber, and intact cysts were counted and then sorted by micropipetting

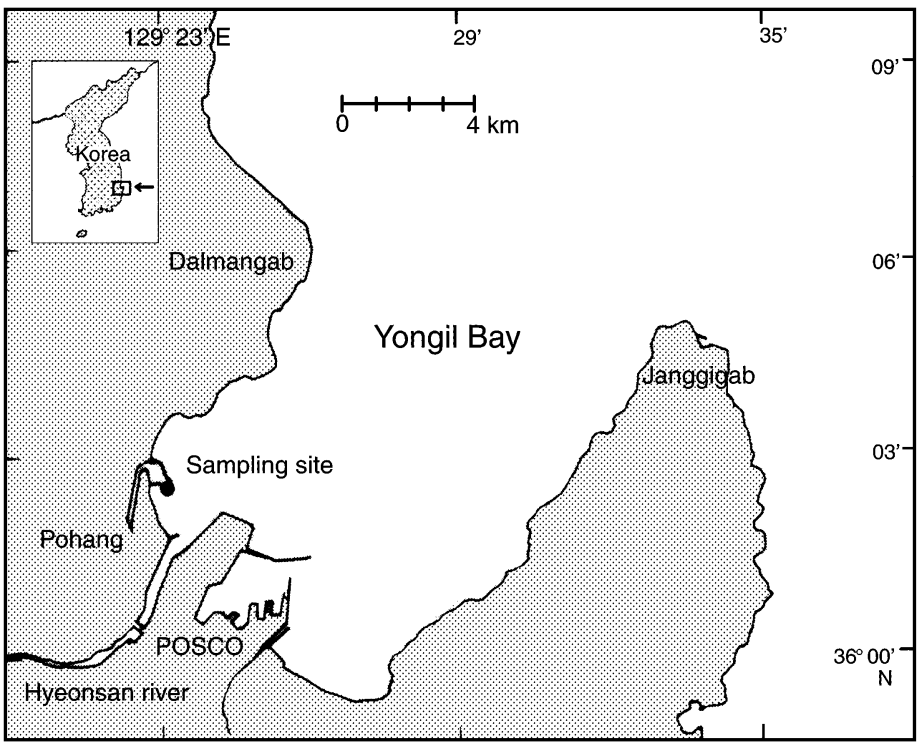

Fig. 1. Sampling site in Yongil Bay on the southeastern coast of Korea 
using a capillary pipette under an inverted microscope. As Scrippsiella trochoidea cysts have a thick and dark wall with numerous calcareous spines, cellular contents are invisible except for a bright red body. Intact cysts with a red body or without an archeopyle were considered to be live, germinable cells. The sorted cysts were quickly washed in cooled, sterilefiltered seawater, and inoculated 1 by 1 into wells of tissue-culture plates (Nunclone Microwell No. 67008, 96 wells) filled with the same filtered seawater and placed on a coolant bag during sorting. This preparation was completed within $3 \mathrm{~d}$ after sediment sampling. The sorted cysts were incubated at the water temperatures measured at $6 \mathrm{~m}$ depth at the sampling station (see Fig. 2A) and ca $12 \mu \mathrm{mol}$ photons $\mathrm{m}^{-2} \mathrm{~s}^{-1}$ cool-white illumination under a 12:12 $\mathrm{h}$ light:dark $(\mathrm{L}: \mathrm{D})$ cycle. For the first week, germination of cysts was confirmed daily under an inverted microscope. Those cysts that had not germinated within 1 wk were checked at 3 to $5 \mathrm{~d}$ intervals. The germination ratio was calculated as a ratio of cumulative excystment over $30 \mathrm{~d}$ to the number of inoculated cysts. Each experiment with 20 to 90 cysts was performed in duplicate or triplicate, depending on the number of cysts sorted after each sampling.

Dormant period measurement. To obtain strains of Scrippsiella trochoidea cysts, 20 cysts were isolated from the sediment samples collected in July 1997 and incubated individually under the above light conditions at $15^{\circ} \mathrm{C}$ (ambient temperature was 14 to $16^{\circ} \mathrm{C}$ at the time of sampling). Of the 20 cysts, 7 germinated within $3 \mathrm{~d}$. Each cell was isolated and transferred into larger wells of tissue-culture plates (Nunclone Microwell No. 143982, 24 wells) filled with the filtered seawater. Without additional nutrients, the vegetative cells of the 7 strains were cultured at $18^{\circ} \mathrm{C}$ and ca $50 \mu \mathrm{mol}$ photons $\mathrm{m}^{-2} \mathrm{~s}^{-1}$ of light under a 12:12 h L:D cycle. Encystments were observed after $1 \mathrm{mo}$ from 3 of the 7 vegetative strains. From the 3 strains, 15, 25 and 52 synchronized cysts were isolated and cultured at $18^{\circ} \mathrm{C}$ and $12 \mu \mathrm{mol}$ photons $\mathrm{m}^{-2} \mathrm{~s}^{-1}$ of light under a 12:12 h L:D cycle.
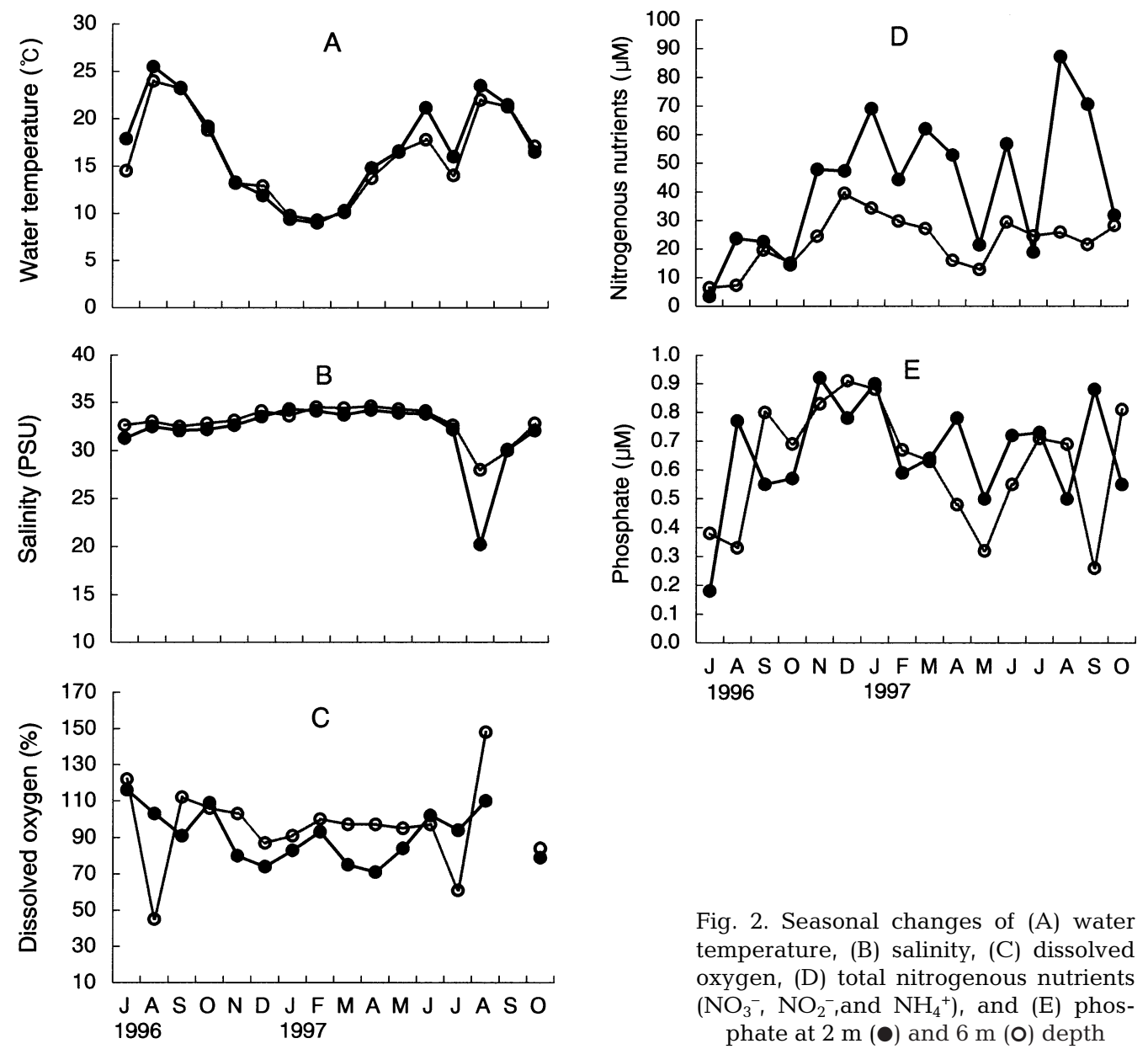

Fig. 2. Seasonal changes of (A) water temperature, (B) salinity, (C) dissolved oxygen, (D) total nitrogenous nutrients $\left(\mathrm{NO}_{3}{ }^{-}, \mathrm{NO}_{2}{ }^{-}\right.$, and $\left.\mathrm{NH}_{4}{ }^{+}\right)$, and (E) phosphate at $2 \mathrm{~m} \mathrm{( \bullet )} \mathrm{and} 6 \mathrm{~m} \mathrm{(O)} \mathrm{depth}$ 


\section{RESULTS}

\section{Hydrographic conditions}

Over the study period, water temperature at 2 and $6 \mathrm{~m}$ depth displayed a clear seasonal cycle. Temperatures $<10^{\circ} \mathrm{C}$ were recorded from January to February and those $>20^{\circ} \mathrm{C}$ from August to September (Fig. 2A). The seasonal maxima in August were $25.5^{\circ} \mathrm{C}$ in 1996 and $23.5^{\circ} \mathrm{C}$ in 1997 at $2 \mathrm{~m}$ depth. In February 1996, minimum temperature was $9.0^{\circ} \mathrm{C}$ at $2 \mathrm{~m}$. A rapid increase in water temperature was recorded between July and August in 1996. Similarly, an abrupt drop in water temperature between June and July 1997 was followed by a rapid increase to the seasonal maximum in August $\left(23.5^{\circ} \mathrm{C}\right.$ at $2 \mathrm{~m}$ and $22.0^{\circ} \mathrm{C}$ at $\left.6 \mathrm{~m}\right)$. Therefore, the change in water temperatures from June to August was very dynamic.

Salinity varied between 20.2 psu in August 1997 and $34.3 \mathrm{psu}$ in January 1997 at $2 \mathrm{~m}$, and exhibited little temporal change except for a sharp decrease after heavy rainfall in August 1997 (Fig. 2B). Seasonal changes in salinity were not remarkable compared with those in water temperature. Significant negative relationships were observed between salinity and temperature at $2 \mathrm{~m}(\mathrm{r}=-0.508, \mathrm{p}<0.05)$ and $6 \mathrm{~m}(\mathrm{r}=$ $-0.606, \mathrm{p}<0.05)$.

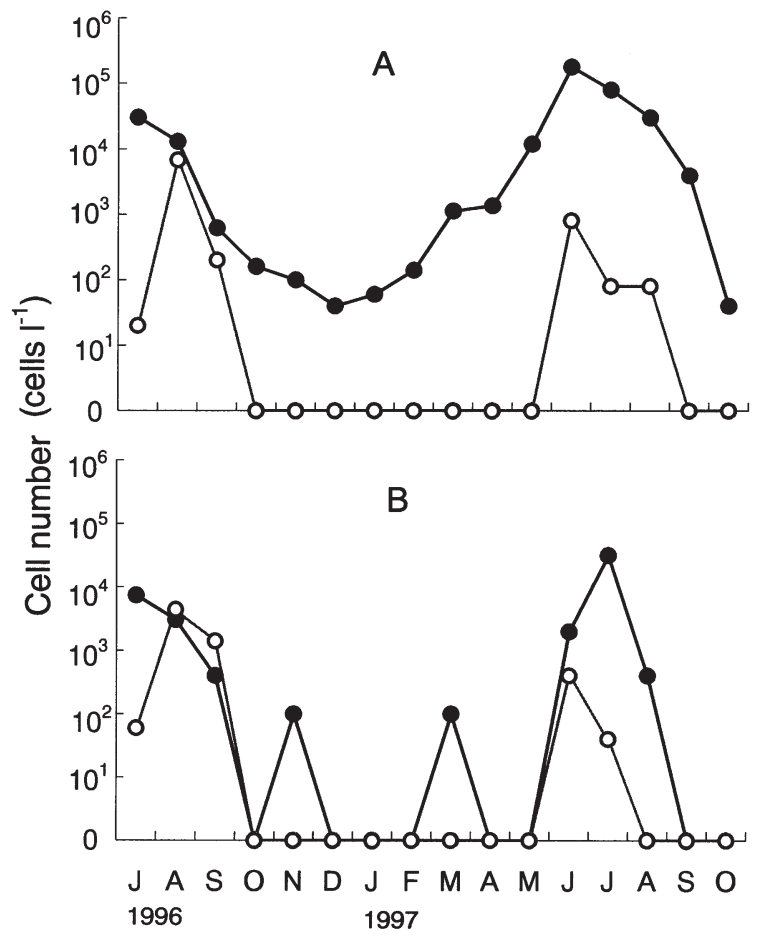

Fig. 3. Scrippsiella trochoidea. Seasonal changes in vegetative cell number ( $\bullet$ and cyst abundance (0) at $2 \mathrm{~m} \mathrm{(A)}$ and $6 \mathrm{~m}$ (B) depth
Through most of the study period, oxygen saturation at $6 \mathrm{~m}$ exceeded $80 \%$, except for the seasonal minima (45\%) in August 1996 and (61\%) in July 1997 (Fig. 2C). The study area was not seriously affected by anoxic conditions. Oxygen saturation at $2 \mathrm{~m}$ tended to be lower than at $6 \mathrm{~m}$, and relatively lower during the lowtemperature season. There was a significant positive relationship ( $\mathrm{r}=0.624, \mathrm{p}<0.05)$ between temperature and dissolved oxygen at $2 \mathrm{~m}$ depth.

Compared with water temperature, salinity and dissolved oxygen, nutrient concentrations varied considerably over the study period. Nutrients were generally very high because the sampling station is located near the entrance of Pohang Port, where domestic waste is discharged. The concentration of total nitrogenous nutrients $\left(\mathrm{NO}_{3}{ }^{-}, \mathrm{NO}_{2}{ }^{-}\right.$, and $\left.\mathrm{NH}_{4}{ }^{+}\right)$at $2 \mathrm{~m}$ was higher than at $6 \mathrm{~m}$ (Fig. 2D), especially so for the maximum $(87.3 \mu \mathrm{M})$, detected at $2 \mathrm{~m}$ in August 1997 after heavy rainfall. In the low-temperature season from November to April, comparatively higher concentrations (44.3 to $69.1 \mu \mathrm{M})$ were recorded. Phosphate displayed a somewhat similar trend at the 2 depths, without any apparent seasonality (Fig. 2E), being $>0.2 \mu \mathrm{M}$ at both depths over the whole period.

\section{Seasonal changes in vegetative cells and cysts}

The vegetative population of Scrippsiella trochoidea in the water column showed a regular seasonal cycle. Vegetative cells occurred at $2 \mathrm{~m}$ in all seasons. The increase in cell numbers started in March, with the temperature rising to $>10^{\circ} \mathrm{C}$, and reached its peak in June to July when the water temperature was $>18^{\circ} \mathrm{C}$ (Figs. 2A \& 3) but before the abrupt increase to maximum temperature. From August to December, the density of the vegetative population gradually decreased, concurrent with the drop in temperature. The abrupt change in temperature from ca 17 to $23-25^{\circ} \mathrm{C}$ occurred in both years from July to August, and corresponded to a decline in vegetative cell numbers. Maximum $\left(3.6 \times 10^{8}\right.$ cells m$\left.{ }^{-2}\right)$ and minimum $\left(8.0 \times 10^{4}\right.$ cells $\mathrm{m}^{-2}$ ) cell densities were observed in July 1997 and December 1996, respectively. The populations at 2 and $6 \mathrm{~m}$ showed similar trends. However, the seasonal variation of the vegetative population was somewhat unclear at $6 \mathrm{~m}$ because the cells were not detectable by our collecting methods when density is very low.

The cysts in the water samples appeared to have a seasonal cycle similar to that of the vegetative population. The cyst numbers at the 2 depths were not significantly different. The first peak of abundance was observed in August 1996, when the vegetative population showed a decline, and the second was observed during June 1997, when the vegetative population was 


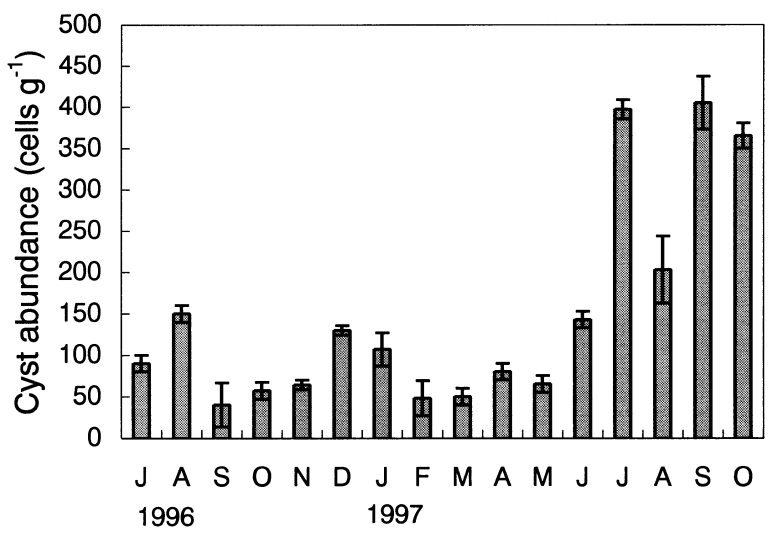

Fig. 4. Scrippsiella trochoidea. Seasonal changes in cyst abundance in sediment. Mean $\pm \mathrm{SD}, \mathrm{n}=3$

also at maximum abundance. An abundance of cysts higher than that of the vegetative cells was observed in August and September 1996. During the season of lower density of vegetative cells, the cysts could not be detected by water sampling.

Cyst abundance in the sediments fluctuated from 59 to 600 cysts $\mathrm{g}^{-1}$ (Fig. 4), and was relatively constant from July 1996 to June 1997. It increased from July 1997, reaching a maximum (405 cysts $\left.\mathrm{g}^{-1}\right)$ in September. The higher abundance recorded in August 1996 and in July 1997 coincided with the higher abundance of cysts in the water samples.

\section{Seasonal changes in germination ratios}

The monthly incubations of cysts revealed seasonally differing germination percentages (Fig. 5). The germination ratio in July 1996 gradually increased with time, but in August, concomitant with the abruptly cumulative increased ratio (ca $58 \%$ ), it took only $4 \mathrm{~d}$ to reach its maximum for that month. There was a dramatic drop to $19 \%$ in September; the ratio quickly recovered again in October, and reached a yearly maximum (50\%) in November 1996. From December 1996 to May 1997, germination decreased progressively to the seasonal minimum (5.1\%) in May 1997. A gradual recovery in germination occurred from June to August 1997, and then, during September and October 1997, the cysts germinated rapidly at high ratios (82 and $75 \%$ ). Therefore, germination ability differed between September 1996 and September 1997.

\section{Dormant period}

We obtained 3 cyst strains from synchronized encystments in laboratory cultures of vegetative cells origi- nating from field cysts collected in July 1997. Fig. 6 presents a series of excystment results. In all 3 strains, excystment started on Day 61 and gathered impetus from Day 70, reaching maximum ratio (ca $60 \%$ ) on Day 96. Therefore, the dormant period of Scrippsiella trochoidea cysts collected from our study area in July 1997 is at least $60 \mathrm{~d}$.

\section{DISCUSSION}

The increasing pollution of coastal waters by urban and industrial sources, especially with nutrients, is considered, at least partially, to be responsible for a worldwide increase in 'nuisance' phytoplankton blooms. Among causative organisms of the blooms, dinoflagellate species, including the dormant cyst stage in their life cycle, are very important members. The shallow and eutrophied water column of the present study area, located at the entrance of a port, has a high potential as a habitual site for such blooms. During most of the sampling period, nitrogenous nutrients and phosphate were present in high concentrations (>20 and $0.5 \mu \mathrm{M}$, respectively). Through the frequent passage of shipping, and through the effects of storms and other natural causes in this shallow water, the sediment at the sampling site could be disturbed, and cysts in sediments could be moved to the mud surface or even into the water column. If the resuspended cysts undergo their dormant period in the sediments and then encounter a suitable environment, they could germinate rapidly and be recruited successfully to the vegetative population. Under good nutritional conditions, the newly germinated cells would divide vegetatively, thus leading to vegetative cell blooms.

Among the cyst-forming dinoflagellates of the study area, the cysts and vegetative cells of Scrippsiella trochoidea were most abundant in the sediments and in the water column, respectively. The rapid increase in water temperature between March and June 1997 coincided with an increase in the vegetative population (Fig. 7). The optimal temperature for both growth of vegetative cells and germination of cysts from Gokasho Bay and Onagawa Bay, Japan, is $20^{\circ} \mathrm{C}$ (Kim \& Iwasaki 1987, Ishikawa 1995). The water temperature in our study area was in the optimal range of 18 to $21^{\circ} \mathrm{C}$ at the time of peak abundance of the vegetative cells in June 1997. Therefore, the vegetative growth of $S$. trochoidea at this site, where nutrients are not limiting, appears to be largely dependent on the water temperature. As the seasonal change of vegetative cell density was well correlated with that of cyst abundance in the water column, the cysts in the water samples are considered to be the product of mass encystment but not of resuspension. During the proliferation of the 

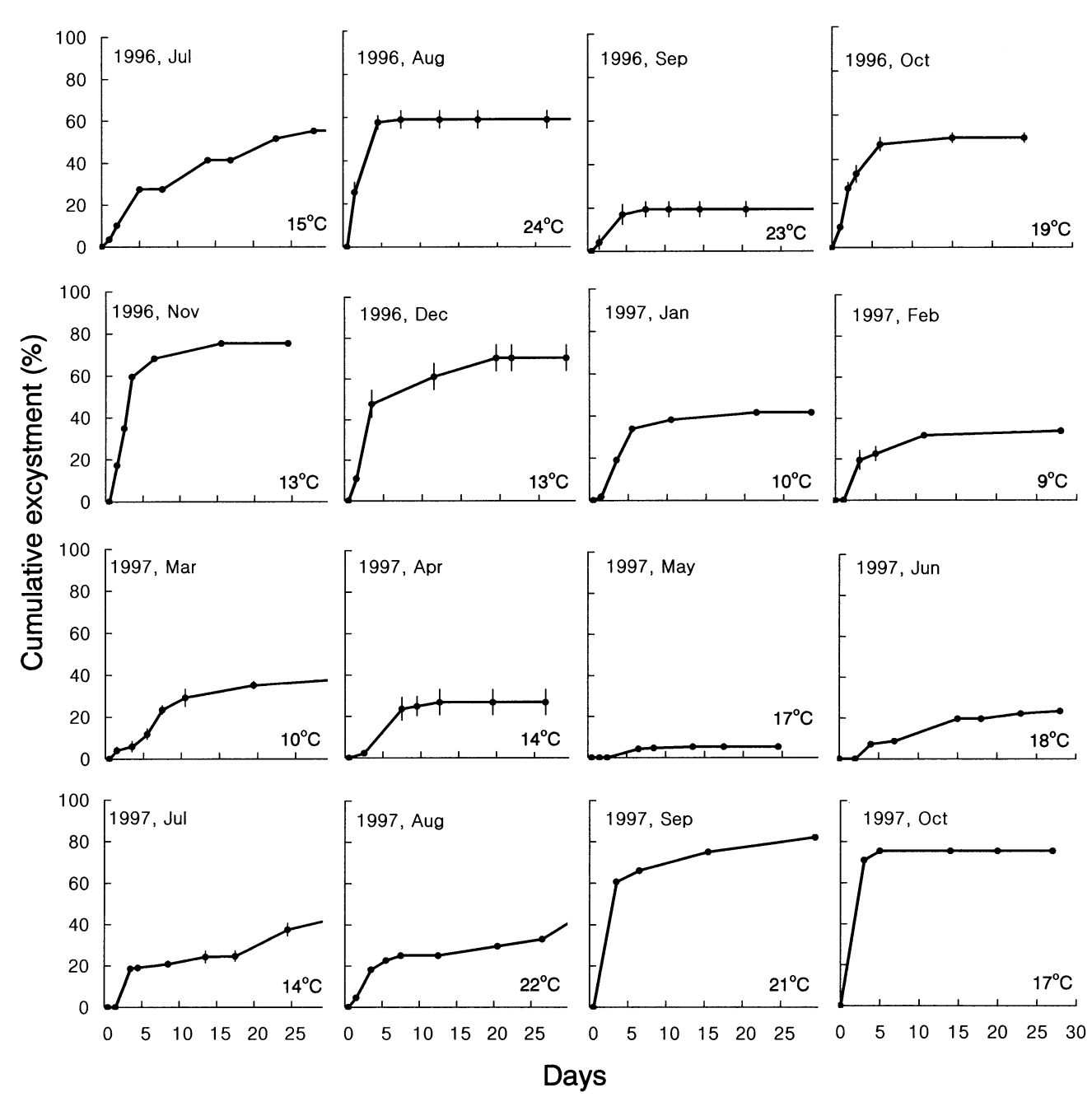

Fig. 5. Scrippsiella trochoidea. Seasonal changes in excystment of cysts collected monthly from Yongil Bay and incubated at ambient $(6 \mathrm{~m})$ water temperatures (Fig. $2 \mathrm{~A}$ ) and $12 \mu \mathrm{mol}$ photons $\mathrm{m}^{-2} \mathrm{~s}^{-1}$ with a 12:12 $\mathrm{h} \mathrm{L}: \mathrm{D}$ cycle. Means $\pm \mathrm{SD}, \mathrm{n}=3$

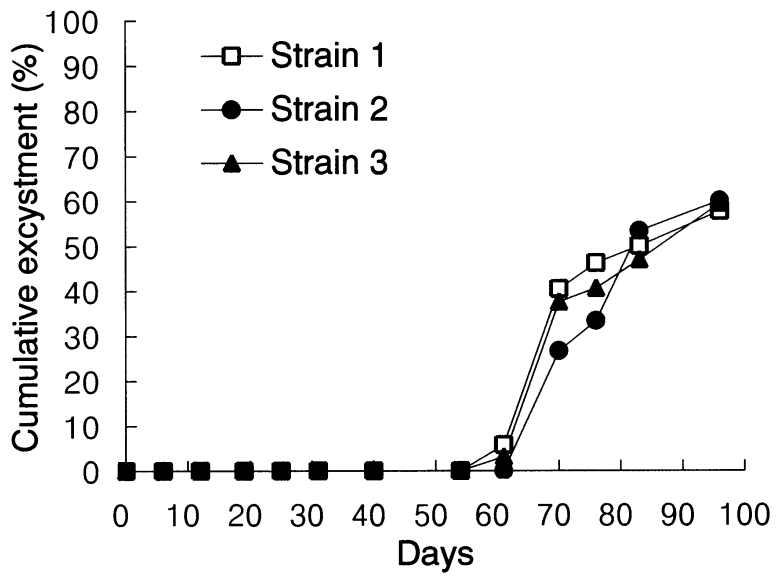

Fig. 6. Scrippsiella trochoidea. Excystment of 3 cyst strains originating from synchronized encystments during laboratory culture of vegetative cells. Encysted cells were incubated at $18^{\circ} \mathrm{C}$ and $12 \mu \mathrm{mol}$ photons $\mathrm{m}^{-2} \mathrm{~s}^{-1}$ vegetative population, 2 events, the growth of the vegetative population by asexual reproduction and cyst formation by sexual reproduction, may be occurring at the same time. The optimal temperature and salinity of encystment is reported to be 20 to $25^{\circ} \mathrm{C}$ and $20 \mathrm{psu}$ (Wall et al. 1970, Watanabe et al. 1982), the same as that for maximal vegetative growth. Thus, the exponential growth of vegetative cells is accompanied by active encystment. Such cyst formation from healthy cells in exponential growth will help to establish healthy seed of $S$. trochoidea.

Based on sediment-trap data in Onagawa Bay (Ishikawa \& Taniguchi 1996), mass encystments of Scrippsiella trochoidea were found to occur in September and October when the bloom of the vegetative population was declining through depletion of cellular nutrient reserves. Encystment can be induced and enhanced by the depletion of nitrogen or phosphate or 
by the addition of sodium bicarbonate, respectively (Watanabe et al. 1982). In our study, peak times of encystment were observed in August 1996 and July 1997. In 1996, there was a trend for rapid increases in several environmental factors: water temperature (17.9 to $25.5^{\circ} \mathrm{C}$ ), salinity ( 31.3 to $32.5 \mathrm{psu}$ ), and nutrients (total nitrogen, 3.4 to $23.7 \mu \mathrm{M}$; phosphate, 0.18 to $0.77 \mu \mathrm{M})$. At the peak encystment period in 1997, however, there was a decrease in water temperature $(21.2$ to $16.0^{\circ} \mathrm{C}$ ), salinity (33.8 to $32.2 \mathrm{psu}$ ), and total nitrogen (56.8 to $18.9 \mu \mathrm{M})$. Therefore, mass encystment of $S$. trochoidea may be induced by the shock caused by abrupt increases or decreases in environmental factors. However, this idea must be regarded as tentative, because the encystment data were obtained monthly from water samples. Continuous collection using sediment traps is necessary to analyze exactly the timing of encystment events, since the sinking velocity of $S$. trochoidea cysts is very high (6 to $11 \mathrm{~m} \mathrm{~d}^{-1}$, Anderson \& Lively 1985).

Most of the monthly germination curves of Scrippsiella trochoidea showed a rapid increase in germination ratios without a lag period after incubation began or a drop in the curves (Fig. 5). This uniform development of the cysts suggests that in this area they are comparatively well synchronized. The concentrated sedimentation of cysts during a short and mass encystment period largely affects the formation of a cyst population of the same age on the sediment surface. However, the natural cyst population is a mixture of several age groups. The main age is determined by the scale of excystment and encystment and the mortality of cysts, and determines the pattern of the germination curve.

A noticeable result was the inverse relationship of the germination ratio to the abundance of the vegetative population. The vegetative population was minimum when the most active germination was recorded (Fig. 8). This suggests that cysts are not a direct contributor to increases in the vegetative population dur-

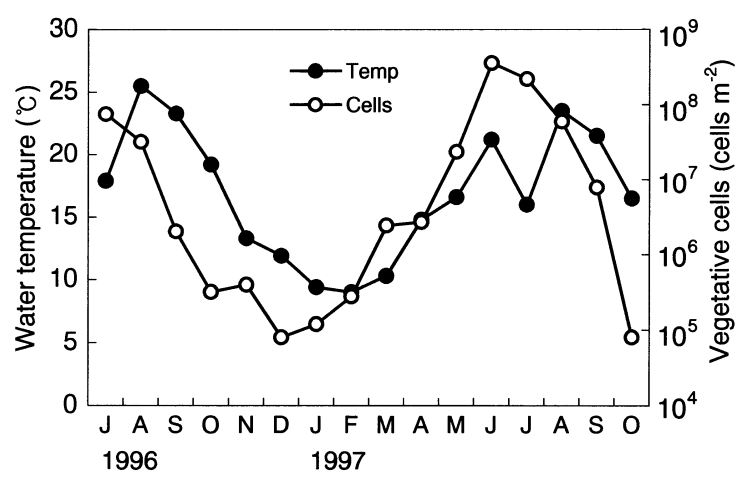

Fig. 7. Scrippsiella trochoidea. Seasonal changes in vegetative cell numbers and water temperature at $2 \mathrm{~m}$

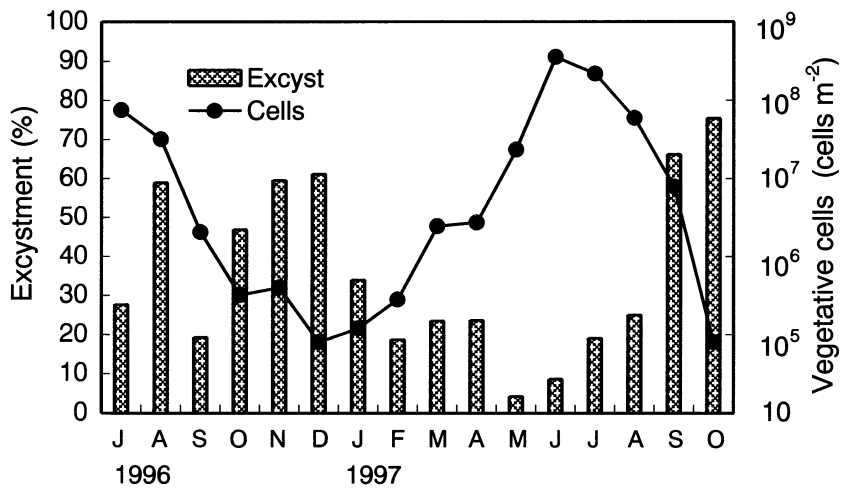

Fig. 8. Scrippsiella trochoidea. Seasonal changes in excystment ratios and vegetative cell numbers

ing the warmer season, but maintain a small vegetative population in the cold season when vegetative growth is low or absent from the water column. Thus, pre-winter excystment might ensure the survival of vegetative cells until the favorable conditions of the warm season. It is puzzling, however, why excystment occurs so early, and not immediately prior to the bloom of the vegetative population. Further investigation should be focused on the possibility of a unique physiological advantage endowed on the winter vegetative population.

In a previous report, the mandatory period of dormancy of Scrippsiella trochoidea measured under laboratory conditions was approximately $25 \mathrm{~d}$ and the duration of this period was not affected by temperature (Binder \& Anderson 1987). This short dormant period could facilitate rapid cycling between resting and vegetative stages in nature. After the dormancy period has been completed, germination is regulated by external factors such as temperature. On the other hand, in the case of Alexandrium tamarense hypnozygotes, the length of the dormant period was affected by storage temperature. While rapid germination was induced after 1 mo of storage at $22^{\circ} \mathrm{C}$, dormancy was extended at $5^{\circ} \mathrm{C}$ (Anderson 1980). Comparable data on dinoflagellate dormancy are based on cyst germination conditioned to habitat temperatures: a 3 mo mandatory resting period was found for Gonyaulax digitale from the Woods Hole region (Wall \& Dale 1968), and a 4 mo resting period for Alexandrium tamarense isolated from $90 \mathrm{~m}$ depth in the Gulf of Maine (Dale et al. 1978). Therefore, ambient temperature is a major factor controlling the duration of the dormant period.

The dormant period of Scrippsiella trochoidea in this study was $\sim 60 \mathrm{~d}$, a period longer than that found by Binder \& Anderson (1987). As the cysts used for the measurement of the dormant period originated from natural sediments in July 1997, the dormant period may reflect that of natural cysts at the same time in 
$s i t u_{i}$ in other words, if cysts in natural sediment germinate in July and then proliferate to a vegetative population and finally encyst again, the encysted cells will germinate in September after undergoing a dormant period for 2 mo. Based on the measured dormant period, this accords well with the germination data, i.e. the abrupt increase in the germination ratio between July, when mass encysment occurred, and September. If the dormant period of 2 mo is applied to1996, the low germination ratio in September can be explained by inactivity of immature cysts which were largely formed in August. Therefore, it seems that the dormant period is not species-specific, but rather variable, with cystsdepending on environmental factors for success in spatial and temporal survival. Consequently, the cyst germination ratio is flexible, according to the age of the cysts, which in turn is based on the time and scale of encystment and the dormant period.

Acknowledgements. We would like to thank E. Lessard for critical comments on the manuscript. We are particularly grateful to K. Banse and R. Horner for improving the clarity of the manuscript. The collaboration in sampling given by M.-H. Park of the Department of Environmental Science of Hanyang University was greatly appreciated. This work was supported by a grant from the Research Institute of Industrial Science and Technology, Pohang, Korea.

\section{LITERATURE CITED}

Adachi R (1972) A taxonomical study of the red tide organisms. J Fac Fish Pref Univ Mie-Tsu 9:9-145 (in Japanese with English abstract)

Anderson DM (1980) Effects of temperature conditioning on development and germination of Gonyaulax tamarensis (Dinophyceae) hypnozygotes. J Phycol 16:166-172

Anderson DM, Keafer BA (1985) Dinoflagellate cyst dynamics in coastal and estuarine waters. In: Anderson DM, White AW, Baden DG (eds) Toxic dinoflagellates. Elsevier, New York, p 219-224

Anderson DM, Lively J (1985) Sinking characteristics of dinoflagellate cysts. Limnol Oceanogr 30:1000-1009

Anderson DM, Morel FMM (1979) The seeding of two red tide blooms by the germination of benthic Gonyaulax tamarensis hypnocysts. Estuar Coast Mar Sci 8:279-293

Anderson DM, Wall D (1978) Potential importance of benthic cysts of Gonyaulax tamarensis and G. excavata in initiating toxic dinoflagellate blooms. J Phycol 14:224-234

Binder BJ, Anderson DM (1987) Physiological and environmental control of germination in Scrippsiella trochoidea (Dinophyceae) resting cysts. J Phycol 23:99-107

Braarud T (1951) Salinity as an ecological factor in marine phytoplankton. Physiol Plant 4:28-34

Dale B, Yentsch CM, Hurst JW (1978) Toxicity in resting cysts of the red tide dinoflagellate Gonyaulax excavata from deeper water coastal sediments. Science 201: 1223-1225

Harland R (1983) Distribution maps of Recent dinoflagellate

Editorial responsibility: Karl Banse (Contributing Editor), Seattle, Washington, USA cysts in bottom sediments from the North Atlantic Ocean and adjacent seas. Palaeontology 26:321-387

Ishikawa A (1995) Population dynamics of Scrippsiella spp. and other cyst-forming armored dinoflagellates with special reference to the role of cysts. PhD thesis, Tohoku University, Sendai

Ishikawa A, Taniguchi A (1994) The role of cysts on population dynamics of Scrippsiella spp. (Dinophyceae) in Onagawa Bay, northeast Japan. Mar Biol 119:39-44

Ishikawa A, Taniguchi A (1996) Contribution of benthic cysts to the population dynamics of Scrippsiella spp. (Dinophyceae) in Onagawa Bay, Northeast Japan. Mar Ecol Prog Ser 140:169-178

Ishikawa A, Taniguchi (1997) In situ germination patterns of cysts, and bloom formation of some armored dinoflagellates in Onagawa Bay, north-east Japan. J Plankton Res 19:1783-1791

Kim $\mathrm{CH}$, Iwasaki $\mathrm{H}$ (1987) Encystment and excystment in the marine dinoflagellate Scrippsiella trochoidea. Korean J Phycol 2:211-221

Matsuoka K, Fukuyo Y, Anderson DM (1989) Methods for modern dinoflagellate cyst studies. In: Okaichi T, Anderson DM, Nemoto T (eds) Red tides: biology, environmental science, and toxicology. Elsevier, New York, p 461-479

Montagnes DJS, Lynn DH (1987) A quantitative protargol stain (QPS) for ciliates: method description and test of its quantitative nature. Mar Microb Food Webs 2:83-93

Nehring S (1994) Spatial distribution of dinoflagellate resting cysts in Recent sediments of Kiel Bight, Germany (Baltic Sea). Ophelia 39:137-158

Park JS, Kim HG, Lee SG (1989) Studies on red tide phenomena in Korean coastal waters. In: Okaichi $T$, Anderson DM, Nemoto T (eds) Red tides: biology, environmental science, and toxicology. Elsevier, New York, p 37-40

Parsons T, Maita Y, Lalli CM (1984) A manual of chemical and biological methods for seawater analysis. Pergamon Press, New York

Qin XM, Zhou JZ, Qian PY (1997) Effects of Fe and Mn on the growth of a red tide dinoflagellate Scrippsiella trochoidea (Stein) Loeblich III. Chin J Oceanol Limnol 15:173-180

Reid PC (1972) Dinoflagellate cyst distribution around the British Isles. J Mar Biol Assoc UK 52:939-944

Silva ES (1962) Some observation on marine dinoflagellate cultures. III. Gonyaulax spinifera (Clap. And Lach.) Dies., Gonyaulax tamarensis Leb., and Peridinium trochoideum (Stein) Lemm. Notas Estud Inst Biol Mar Lisbon 26:1-24

Walker LM, Steidinger KA (1979) Sexual reproduction in the toxic dinoflagellate Gonyaulax monilata. J Phycol 15: 312-315

Wall D, Dale B (1968) Modern dinoflagellates cysts and evolution of the Peridiniales. Micropaleontology 14:265-304

Wall D, Guillard RRL, Dale B, Swift E, Watabe N (1970) Calcitic resting cysts in Peridinium trochoideum (Stein) Lemmermann, an autotrophic marine dinoflagellate. Phycologia 9:151-156

Wall D, Dale B, Lohmann GP, Smith WK (1977) The environmental and climatic distribution of dinoflagellate cysts in modern marine sediments from regions in the North and South Atlantic Oceans and adjacent seas. Mar Micropaleontol 2:121-200

Watanabe MM, Watanabe M, Fukuyo Y (1982) Encystment and excystment of red tide flagellates. I. Introduction of encystment of Scrippsiella trochoidea. Res Rep Natl Inst Environ Stud 30:27-42

Submitted: April 6, 1999; Accepted: March 27, 2000

Proofs received from author(s): September 11, 2000 